\title{
HUBUNGAN PENGEMBANGAN KARIR PERAWAT TERHADAP KUALITAS PELAYANAN KEPERAWATAN DI RUMAH SAKIT
}

\author{
RELATIONSHIP OF NURSE CAREER \\ DEVELOPMENT TO QUALITY OF NURSING \\ SERVICES IN HOSPITAL
}

\author{
Yayan Hardiansah1, \\ ${ }^{1}$ Dosen Keperawatan dan Profesi Ners Universitas Qamarul Huda Badaruddin Bagu
}

\begin{abstract}
Latar Belakang: pengembangan karir perawat merupakan suatu perencanaan, penerapan dari rencana karir .Perubahan telah menjadi suatu norma dan menciptakan suatu lingkungan dimana individu harus dapat mengontrol karirnya. Dengan dilaksanakannya pengembangan karir akan dapat mengontrol karirnya dan mencapai karir yang lebih baik serta pelayanan keperawatan yang bai. Tujuan, mengetahui pengembangan karir perawat berdasarkan kebijakan rumah sakit terhadap mutu pelayanan keperawatan di rsud tugurejo semarang dan rsi sultan agung semarang. Metode : Jenis penelitian adalah diskriptik analitik dengan menggunakan croos sectional. Populasi seluruh perawat pelaksana yang bertugas di instalasi rawat inap dengan populasi 453 di rsud tugurejo semarang dan 262 perawat manajer di rsi sultan agung semarang 2017. Penentuan sampel menggunakan stratified random sampling. dianalisis meliputi univariat, bivariat, multivariat dengan uji regresi logistik . Data menggunakan kuesioner. Hasil : Terdapat hubungan yang signifikan antara pengembangan karir perawat dengan pelaksanaa mutasi rotasi terhadap mutu pelayanan keperawtan di rsud tugurejo semarang dengan $p=0,039$ dan exo ( $b$ ) 0,369
\end{abstract}

Kata Kunci : Pengembangan Karir Perawat, Rotasi mutasi, romosi, Pendidikan, Pelatihan, Kualitas Yankep

\section{ABSTRAK}

Background: nursing career development is a planning and implementation of a career plan Change has become the norm and creates an environment in which individuals must be able to control their careers. With the implementation of career development, you will be able to control your career and achieve a better career and good nursing services. The purpose of this study was to determine the career development of nurses based on hospital policies on the quality of nursing services at Tugurejo General Hospital Semarang and Sultan Agung Hospital Semarang. Methods: The type of research is descriptive analytic using cross sectional. The population of all implementing nurses on duty in inpatient installations with a population of 453 at Tugurejo General Hospital Semarang and 262 nurse managers at Sultan Agung Hospital Semarang 2017. Determination of the sample using stratified random sampling. analyzed include univariate, bivariate, multivariate 
with logistic regression test. Data using a questionnaire. Results: There is a significant relationship between the career development of nurses with the implementation of rotational mutations on the quality of nursing services at Tugurejo Hospital, Semarang with $p=0.039$ and exo (b) 0.369

Keywords : Career development nurse, rotation mutation, promotion, education, training , the quality of yankep

\begin{tabular}{ll}
\hline Alamat Korespondensi & $\begin{array}{l}\text { : Keperawatan dan Profesi Ners Universitas Qamarul Huda } \\
\text { Badaruddin Bagu }\end{array}$ \\
Email & : adingsin@gmail.com \\
\hline
\end{tabular}

\section{PENDAHULUAN}

Perencanaan karir secara terus menerus merupakan strategi yang dapat menawarkan berbagai cara untuk merespons perubahan jangka pendek dan jangka panjang dalam profesi, pelayanan kesehatan, tempat kerja, sehingga Jenjang karir diperlukan untuk terwujudnya asuhan keperawatan yang bemutu mengingat perawat mempunyai tenaga terbanyak dan terlama mendampingi pasien (Nursalam, 2011).

Menurut penelitian yang dilakukan Azwir (2008) di RSUD Tarakan bahwa RSUD Tarakan memiliki tenaga keperawatan sebanyak 245 orang dengan karakteristik: (1) mayoritas tenaga keperawatan berada pada kelompok umur 25-44 tahun (77,96\%), (2) memiliki masa kerja terbesar pada kelompok $>3$ tahun (61,22\%), (3) dengan latar belakanpendidikan D II Keperawatan sebanyak 72,24\%, (4) serta PNS 41,22\%. Pelaksanaan pengembangan karir perawat klinik tidak dilakukan berdasarkan uji kompetensi. Komite keperawatan juga tidak menjalankan peran sebagaimana mestinya. Ini menunjukkan bahwa pengembangan karir perawat masing-masing rumah sakit berbeda dan dipengaruhi oleh beberapa faktor seperti motivas minat, kesempatan pegawai dan dukungan pimpinan serta ketersediaan dana Pendidikan. pengembangan karir merupakan suatu proses dalam peningkatan dan penambahan kemampuan seseorang karyawan yang dilakukan secara formal dan berkelanjutan untuk mencapai sasaran dan tujuan karirnya. Sedangkan pengertian pengembangan karir dalam definisi yang lain diartikan sebagai perolehan pengetahuan, ketrampilan, dan perilaku yang meningkatkan kemampuan karyawan untuk memenuhi perubahan persyaratan pekerjaan serta tuntutan klien dan pelanggan (Raymond, 2010: 523). Dalam pengertian ini, pengembangan karir didefinisikan lebih luas, karena pengembangan karir lebih kepada seluruh kegiatan atau aktivitas kemampuan dari seseorang. Salah satu cara yang dilakukan RS untuk meningkatkankompetensi perawat adalah dengan sistem jenjang karir. Sistem jenjang karir perawat memberikan pengakuan dan penghargaan atas kontribusi perawat dalam memberikan pelayanan keperawatan yang berkualitas dan berdasarkan pada evidence based practice, sehingga memberikan dampak positif terhadap hasil yang dicapai pasien (Burket, 2010). Dalam pelaksanaan pengambangan karir yang dilaksanakan di rumah sakit dapat memberikan manfaat bagi perawta di rumah sakit. Tetapi, perawat sering kali 
memiliki sedikit fokus karir dan biasanya melihat keperawatan sebagai pekerjaan dan bukan karir. Maka untuk menghindari keusangan dan membangun keterampilan baru Akibat perubahan yang cepat pada industri layanan kesehatan, terutama dalam area tuntutan konsumen dan teknologi Perlu dilakukan Program pengembangan karir dengan mulai melatih kembali pegawai secara proaktif, memberikan mereka keterampilan yang diperlukan agar tetap terkini dalam bidang mereka dan sehingga menjadi berharga bagi organisasi. Pelatihan ulang juga memberikan kesempatan bagi pegawai untuk bertahan dari pengurangan pegawai.

Dengan adanya program pengembangan karir akan meningkatkan kualitas kerja perawat, dimana perawat akan berusaha mengontrol karirnya dan mencapai karir yang lebih baik sehingga ia akan terus berprestasi dan memperoleh kepuasan kerja (Marquis \&Huston, 2010). Dengan pencapaian karir yang lebih baik pada perawat dan memiliki kepuasan kerja yang baik, maka perawat akan mmberikan dampak yang baik pula terhadap kualitas pelayanan terhadap pasien. Pelayanan keperawatan dikatakan berkualitas apabila pelayanan keperawatan yang diberikan sesuai dengan standar yang ditetapkan, untuk mengukur seberapa baik mutu pelayanan keperawatan yang diberikan diperlukan suatu indicator klinik mutu pelayanan keperawatan (Depkes, 2008). Kualitas pelayanan keperawatan yang baik berarti pasien mendapat layanan yang cepat, diagnosis dan terapi yang tepat, keramah tamahan yang cukup, pelayanan administrasi yang cepat dan biaya yang terjangkau. Dengan demikian pelayanan yang diberikan adalah untuk memenuhi keinginan pelanggan (Menurut Lewis \& Booms, 2012).

Kualitas berkaitan erat dengan kepuasan pelanggan. Kualitas memberikan dorongan khusus bagi para pelanggan untuk menjalin ikatan relasi saling menguntungkan dalam jangka panjang dengan perusahaan. Selain itu, perusahaan juga dapat meningkatkan pangsa pasarnya melalui pemenuhan kualitas yang bersifat customer-driven. Hal ini akan memberikan keunggulan harga dan customer value. Customer value merupakan kombinasi dari manfaat dan pengorbanan yang terjadi apabila pelanggan menggunakan suatu barang atau jasa guna memenuhi kebutuhan tertentu (Bounds, et., 1994 dalam Fandi \& Gregorius, 2011).Kualitas juga dapat mengurangi biaya. Fandi \& Gregorius (2011) meyatakan bahwa "Quality is Free". Biaya untuk mewujudkan produk berkualitas jauh lebih kecil dibandingkan biaya yang ditimbulkan apabila perusahaan gagal memenuhi standar kualitas.

Berdasarkan beberapa penjelasan dan penelitian terdahulu yang ada, maka tampak bahwa jenjang karir perawat khususnya perawat pelaksana yang dilaksanakan di Rumah Sakit belum sesuai dengan peran dan fungsi perawat, sehingga perlu adanya suatu pola jenjang karir perawat klinik yang dapat mempengaruhi kualitas pelayanan keperawatan di RSUD Tugurejo Semarang.

Penelitian ini difokuskan pada pengembangan karir perawat berdasarkan kebijakan rumah sakit (Negri dan Swasta) yang dapat memberikan dampak baik terhadap kualitas pelayanan keperawatan di rumah sakit 


\section{METODE PENELITIAN}

Penelitian ini adalah deskriptif analitik dengan rancangan cross sectional untuk melihata apakah ada dampak dari pengembangan karir perawat terhadap kualitas pelayanan keperawatan di RSUD Tugurejo Semarang dan RSI Sultan Agung Semarang. Sampel dalam penelitian ini adalah perawat pelaksana di ruang rawat inap dan pasien RSUD Tugurejo Semarang dan RSI Sultan Agung Semarang. Sampel diambil dengan teknik stratified random sampling. .Kriteria inklusi pada perawat adalah perawat di ruang rawat inap yang mempunyai masa kerja lebih dari satu tahun, tidak dalam keadaan cuti. Kriteria inklusi pada pasien adalah pasien yang berada di ruang rawat inap, pasien yang sudah mendapatkan perawatan minimal tiga hari rawat. Jumlah sampel di RSUD Tugurejo Semarang sebanyak 82 perawat. RSI Sultan Agung Semarang sebanyak 72 perawat.Data dikumpulkan menggunakan kuesioner Pengembangan karir perawat dan kuesioner kualitas pelayanan.

Hasil uji validitas menggunakan Pearson product moment didapatkan nilai antara 0,187- 0,844. Hasil uji reliabilitas instrumen dengan alpha cronbach didapatkan $\mathrm{r}=0,959$. Penelitian ini mempertimbangkan prinsip dasar etik penelitian keperawatan yaitu menghormati harkat dan martabat manusia, menghormati privasi dan kerahasiaan subjek, menghormati keadilan dan inklusivitas, serta memperhitungkan manfaat dan kerugian yang ditimbulkan.

\section{HASIL DAN PEMBAHASAN}

\section{HASIL}

\section{Karakteristik responden RSUD Tugurejo Semarang dan RSI Sultan Agung Semarang}

\section{RSUD Tugurejo Semarang}

Sebagian besar jenis kelamin responden adalah perempuan $(78,0 \%)$,umur responden terbesar adalah lebih dari 30 tahun , dan lama kerja yang paling banyak adalah lebih dari 5 tahun (40,2\%), serta Tingkat Pendidikan terbanyak pada jenjang Pendidikan D3 (41,5\%)

\section{RSI Sultan Agung Semarang}

Sebagian besar jenis kelamin responden adalah perempuan $(66,7 \%)$,umur responden terbesar adalah 25-30 tahun (41,7\%), dan lama kerja yang paling banyak adalah lebih dari 5 tahun dan 1-2 tahun (38,9\%), serta Tingkat Pendidikan terbanyak pada jenjang Pendidikan D3 (61,1\%).Pengembangan karir perawat dan kualitas pelayanan dijelaskan secara rinci padatable 
Table 1.Distribusi Frekuensi Responden Terhadap Pengembangan Karir Perawat DI RSUD Tugurejo Seamarang, $2017(n=82)$

\begin{tabular}{lcc}
\hline Variabel & Frekuensi & $\begin{array}{l}\text { Persentase } \\
(\%)\end{array}$ \\
\hline Rotasi & & \\
Mutas & 4 & 56 \\
Kurang baik & 6 & $\%$ \\
Baik & 3 & 44 \\
& 6 & $\%$ \\
\hline Promosi & & \\
Kurang baik & 5 & 61 \\
Baik & 0 & $\%$ \\
& 3 & 39 \\
Pendidik & 2 & $\%$ \\
an & & \\
Kurang & 4 & 55 \\
baik Baik & 5 & $\%$ \\
& 3 & 45 \\
Pelatihan & 7 & $\%$ \\
Kurang baik & 4 & \\
Baik & 8 & 59 \\
& 3 & 41 \\
& 4 & $\%$ \\
\hline
\end{tabular}

Table 2. Distribusi Frekuensi Responden Trehadap Kualitas Pelayanan Keperawatan DI RSUD Tugurejo Seamarang, 2017 (n=82)

\begin{tabular}{|c|c|c|}
\hline $\begin{array}{l}\text { Kualitas } \\
\text { pelayanan } \\
\text { Keperawatan }\end{array}$ & $\begin{array}{l}\text { Jumla } \\
\text { h }\end{array}$ & $\begin{array}{l}\text { Persentase } \\
(\%)\end{array}$ \\
\hline Kurang & 43 & $52 \%$ \\
\hline Baik Baik & 39 & $48 \%$ \\
\hline Jumlah & 82 & 100,0 \\
\hline
\end{tabular}

Table 3. Distribusi Frekuensi Responden Terhadap Pengembangan Karir Perawat DI RSI Sultan Agung Semarang, $2017(n=72)$

\begin{tabular}{lll}
\hline \multicolumn{1}{c}{ Variabel } & $\begin{array}{l}\text { Frekuen } \\
\text { si }\end{array}$ & $\begin{array}{l}\text { Persentase } \\
(\%)\end{array}$ \\
\hline Rotasi & & \\
$\begin{array}{l}\text { Mutas } \\
\begin{array}{l}\text { Kurang baik } \\
\text { Baik }\end{array}\end{array}$ & 37 & $\begin{array}{l}51 \% \\
49 \%\end{array}$ \\
\hline jumlah & 72 & $100 \%$ \\
\hline $\begin{array}{l}\text { Promosi } \\
\begin{array}{l}\text { Kurang baik } \\
\text { Baik }\end{array}\end{array}$ & 46 & $64 \%$ \\
Jumlah & 26 & $36 \%$ \\
\hline $\begin{array}{l}\text { Pendidik } \\
\text { an }\end{array}$ & 59 & $100 \%$ \\
\hline
\end{tabular}




\begin{tabular}{lll}
\hline $\begin{array}{l}\text { Kurang } \\
\text { baik Baik }\end{array}$ & 13 & $18 \%$ \\
\hline Jumlah & 72 & $100 \%$ \\
\hline $\begin{array}{l}\text { Pelatihan } \\
\text { Kurang baik }\end{array}$ & 49 & $68 \%$ \\
Baik & 23 & $32 \%$ \\
\hline Jumlah & 72 & $100 \%$ \\
\hline
\end{tabular}

Table 4. Distribusi Frekuensi Responden Terhadap Kualitas Pelayanan Keperawatan DI RSI Sultan Agung Semarang, 2017 (n=72)

\begin{tabular}{lcc}
\hline $\begin{array}{c}\text { Kualitas } \\
\text { pelayanan } \\
\text { Keperawatan }\end{array}$ & $\begin{array}{l}\text { Jumla } \\
\text { h }\end{array}$ & $\begin{array}{c}\text { Persenta } \\
\text { se } \\
(\%)\end{array}$ \\
\hline Kurang & 38 & $53 \%$ \\
Baik Baik & 34 & $47 \%$ \\
\hline Jumlah & 82 & 100,0 \\
\hline
\end{tabular}

Tabel 5. Hubungan Antara Pengembangan Karir Perawat Terhadap Kualitas Pelayanan keperawtan di RSUD Tugurejo Semarang, 2017

\begin{tabular}{lll}
\multicolumn{1}{r}{ Variabel } & Sig. & OR \\
\hline Rotasi mutasi & .039 & .369 \\
\hline promosi & .319 & 1.750 \\
\hline pendidikan & .148 & .454 \\
\hline Constant & 1.693 & .945 \\
\hline
\end{tabular}

Hasil penelitian disimpulkan dapat dilihat variable yang berhubungan dengan kualita pelayanan keperawatan adalah pelaksanaan rotasi mutasi, hasil analisis didapatkan $\mathrm{p}$ value dari variabel rotasi mutasi adalah 0,369 yang dimana artinya perawat menyatakan rotasi mutasi akan memberikan kualitas pelayanan keperawtan sebesar 0,4 kali lebih baik di bandingkan dengan perawat yang tidak menyatakan rotasi mutasi baik dalam pengembangan karir perawat.

Table 6. Model Akhir RSI Sultan Agumg Semarang, 2017 (n=72)

\begin{tabular}{lll}
\multicolumn{1}{c}{ Varaibael } & Sig. & \multicolumn{1}{c}{$\operatorname{Exp(B)}$} \\
\hline rotasimutasi & .926 & 1.055 \\
\hline promosi & .480 & 1.517 \\
\hline pendidikan & .189 & 2.524 \\
\hline pelatihan & .860 & 1.106 \\
\hline Constant & .083 & .138 \\
\hline
\end{tabular}

Dari hsil analisis multivariate diatas, teryata tidak variable yang berhubungan bermakna dengan kualitas pelayanan keperawatan. Tetapi dapat di lihat variabel yang paling besar pengaruhnya terhadak kualitas pelayanan keperawatan, dapat di lihat dari exp (B), pada hasil analisi diatas dapat dilihat 
variabel pendidikan memiliki pengaruh yang besar dengan jumlah exp (B) 2,590, artinya perawat yang menyatakan pendidikan akanmemberikan kualitas pelayanan keperawtan sebesar 3 kali lebih baik di bandingkan dengan perawat yang tidak menyatakan pendidikan baik dalam pengembangan karir perawat.

Sebagian besar perawat yang menjadi responden di tempat penelitian adalah perempuan. Banyaknya perawat dalam penelitian ini tidak mempengaruhi hasil penelitian karena jenis kelamin tidak berpengaruh pada kinerja, dalam penelitian ini pelaksanaan discharge planning. Robbins dan Judge (2013), menyatakan bahwa tidak ada perbedaan antara laki-laki dan perempuan dalam kinerja, kemampuan memecahkan masalah, keterampilan analisis, motivasi dan dorongan kompetitif.

\section{Pengembangan Karir Perawat Rumah Sakit Terhadap Kuaitas Pelayanan Keperawatan Pelaksana Di RSUD Tugurejo Semarang.}

\section{Pengembangan karir dengan pelaksanaan rotasi mutasi terhadap kualitas pelayanan keperawatan}

Dari hasil penelitian didapatkan suatu hubungan yang bermakna antara pelaksanaan rotasi mutasi terhadap kualitas pelayanan keperawatan. Hasil uji hubungan pelaksanaan rotasi mutasi terhadap kualitas pelayanan keperawtan yang dilakukan menggunakan uji bivariate yaitu uji chi-square 0,039 ( $\mathrm{p}$ valuenya kurang dari 0,05$)$, artinya bahwa pelaksanaan rotasi mutasi memberikan dampak terhadap kualitas pelayanan keperawatan. Hal ini sesuai dengan Hasil penelitian serupa di lakukan oleh Prawoto (2007) di RSUD Koja Jakarta Utara yaitu ada hubugan pengertian rotasi dengan kinerja perawat. Unsitalo (2004) menyatakan ada hubungan rotasi mutasi kerja dengan peningkatan jenjang karir keperawtan. Rotasi kerja adalah perputaran sumber daya manusia (perawat) dari pekerjaan sat uke pekerjaan yang lain yang dianggap setingkat/sejajar (Nitisemito, 2009).

\section{Pengembangan Karir Dengan Pelaksanaan Promosi Terhadap Kualitas Pelayanan Keperawatan Di RSUD Tugurejo Semarang}

Hasil uji hubungan pelaksanaan promosi terhadap kualitas pelayanan keperawatan yang dilakukan menggunakan uji bevariate yaitu uji Chi-Square dimana nilainya adalah 1,000 ( $\mathrm{p}$ value $>0,05$ ). Artinya bahwa pelaksanaan promosi dalam pengembangan karir tidak ada hubungan terhadap kualitas pelayanan keperawatan. Hasil penelitian ini sejalan dengan hasil penelitian serupa yang dilakukan Rudi Prasetyo Ardi, dkk (2016) dengan hasil penelitian menunjukkan bahwa promosi jabatan tidak memiliki pengaruh positif dan signifikan tehadap kinerja pegawai Dinas Kebudayaan Pariwisata Pemuda dan Olahraga Kabupaten Rembang. Promosi adalah penugasan ulang ke posisi yang lebih tinggi. Kenaikan gaji adalah hal yang biasa dalam promosi. Sebagian besar promosi mencakup peningkatan status, perubahan titel, kewenangan yang lebih banyak, dan tanggung jawab yang lebih besar. Karena masyarakat Amerika memandang promosi sebagai hal yang penting, panduan tertentu harus menyertai pemilihan promosi untuk memastikan bahwa proses tersebut adil dan pantas.(Marquis, Bassie L, 2010). 


\section{Pengembangan Karir Dengan Pelaksanann Peningkatan pendidikan Terhadap Kuaitas Pelayanan Keperawatandi RSUD Tugurejo Semarang.}

Hasil uji hubungan pelaksanaan pendidikan terhadap kualitas pelayanan keperawatan yang dilakukan menggunakan uji bevariate yaitu uji Chi-Square adalah 0,169 ( $\mathrm{p}$ value $>0,05$ ). Sehingga dari analisis ini menunjukanhipotesis yang menyatakan bahwa hubungan antara pengembangan karir perawat dengan pelaksaaan peningkatan Pendidikan terhadap kualitas pelayanan keperawatan di RSUD Tugurejo Semarang adalah ditolak. Hasil penelitian ini tidak sesuai dengan teori siagian (2002) dan Baron Byrn (2004). Namun hal ini sesuai dengan hasil penelitian terdahulu yang dilakukan oleh Eman (2004) di RSUD Ambarawa. Yang dimana tidak terbukti adanya hubungan yang bermakna antara Pendidikan dengan kepuasan kerja perawat. Resky (2010) dalam penelitan serupa yang dilaksanakan di RS Zahirah Depok juga mendapatkan hal yang sama, tidak ada hubungan antara tingkat Pendidikan dengan kepuasan kerja perawat. Dengan demikian hasil pengukuran yang dilakukan tidak dapat mendukung teori yang ada, selain itu dalam era globalisasi terjadi kemudahan dalam memperoleh informasi dari berbagai sumber yang dapat meningkatkan pengetahuan perawat unutuk menuntut pekerjaan menjadi lebih baik dan memberikan pelayanan yang baik pula, sehingga dengan memberikan pelayanan yang lebih baik akan memberikan dampak terhadap kualits pelayanan. Informasi yan diperoleh baik dari Pendidikan formal maupun non formal dapat memberikan pengaruh jangka pendek (immediate Impact) sehingga menghasilkan perubahan atau peningkatan pengetahuan (Notoatmodjo, 2003).

\section{Pengembangan Kariri Dengan Pelaksanann Pelatihan Terhadap Kualitas Pelayanan Keperawatan di RSUD Tugurejo Semarang.}

Hasil uji hubungan pelaksanaan pelatihan terhadap kualitas pelayanan keperawatan yang dilakukan menggunakan uji bevariat yaitu uji Chi-Square 0,551 ( $p$ value $>0,05$ ). Artinya bahwa pengembangan karir perawat dengan pelaksanan pelatihan tidak memiliki hubungan terhadap kualitas pelayanan keperawatan. Hal ini berbanding terbalik dengan hipotesis awal yang menyatakan bahwa pelaksanaan pelatihan dapat memberikan dampat terhadap kualitas pelayanan keperawataan. Menurut Marquis dan Huston (2010), pelatihan merupakan salah satu bagian terpenting dalam pengembangan staf. Sulistyani \& Rosidah (2009) menyatakan pelatihan merupakan proses orientasi pada pegawai diberi informasi, pengetahuan tentang kepegawaian, organisasi dan harapan untuk mencapai pelaksanaan kinerja yang baik. Tujuan pelatihan adalah memperbaiki pelaksanaan kinerja pegawai sehingga keahlian pegawai meningkat sesuai dengan kemajuan teknologi. Namun hal ini sesuai dengan hasil penelitian terdahulu yang dilakukan oleh Indah Mawarti (2014) di RSUD Jambi, Yang dimana tidak terbukti adanya hubungan antara pelatihan dengan pelaksanaan sistem pemberian pelayanan keperawatan profesional oleh perawat pelaksana, dimana perawat yang tidak mengikuti pelatihan lebih baik dalam pelaksanaan kerja.

Variabel Pengembangan Karir Perawat Dominan Yang Berhubungan Terhadap Kualitas Pelayanan Keperawatan di RSUD Tugurejo Semarang. 
Hasil analisis yang dilakukan terhadap variabel pengembangan karir perawat terdapat dua variabel yang memenuhi syarat untuk masuk dalam uji multivariat yaitu rotasi mutasi dan Pendidikan. 2 variabel yang ada setelah di analisis terdapat 1 variabel yang berkontribusi terhadap kualitas pelayanan keperawatan, Nilai Odds Ratio (OR) yaitu 0,369 artinya perawat yang mempersepsikan pengembangan karir denan pelaksanaan rotasi mutasi baik akan memberikan pelayanan keperawatan 0,4 Kali lebih baik dibandingkan dengan perawat yang mempersepsikan pengembangan karir perawat dengan pelaksanaan rotasi mutasi yang kurang baik. Hasil diatas dapat diinterpretasikan bahwa kualitas pelayanana keperawatan lebih dominan di pengaruhi oleh pelaksanaan rotasi mutasi kerja yang telah dijalani oleh perawat. Apabila perawat merasa bahwa rotasi mutasi kerja dapat bermanfaat dalam peroses pengembangan karir perawat maka usaha untuk menghasilkan kualitas pelayanan yang baik akan menjadi kenyataan.

\section{Pengembangan Karir Perawat Berbasis Kebijakan Rumah Sakit Terhadap Kuaitas Pelayanan Keperawatan Pelaksana Di RSI Sultan Agung Semarang. \\ 1. Pengembangan karir dengan pelaksanaan rotasi mutasi terhadap kualitas pelayanan keperawatan}

Hasil uji hubungan pelaksanaan rotasi dan mutasi terhadap kualitas pelayanan keperawtan dilakukan pada di RSI Sultan Agung Semarang yang dilakukan menggunakan uji bivariate yaitu uji chi-square dimana nilai coefficient adalah 0,646 ( $\mathrm{p}$ valuenya kurang dari 0,05 ), artinya bahwa pelaksanaan rotasi mutasi tidak memberikan dampak terhadap kualitas pelayanan keperawatan. hal ini sesuai dengan hasil penelitian serupa Purwaningsih (2007) bahwa perawat mempunyai persepsi dan sikap yang tidak baik terhadap kebijakan rotasi mutasi dimana rotasi mutasi masih dipersepsikan sebagai bentuk sanksi baagi perawat yang mempunyai masalah, adanya kecemasan dan kekhawatiran setiap ada informasi akan dilakukan rotasi mutasi bagi perawat pelaksana di RSI Sultan Agung Semarang.

\section{Pelaksanaan promosi Terhadap Kualitas Pelayanan Keperawatan di RSI Sultan Agung Semarang.}

Hasil uji hubungan pelaksanaan promosi terhadap kualitas pelayanan keperawatan yang dilakukan menggunakan uji bevariate yaitu uji Chi-Square dimana nilai coefficient adalah 0,275 ( $\mathrm{p}$ value $>0,05$ ). Artinya bahwa pelaksanaan promosi yang di lakukan tidak memilik hubugnan yang signifikan terhadap kualitas pelayanan keperawatan. Hasil penelitian ini sejalan dengan hasil penelitian serupa yang dilakukan Rudi Prasetyo Ardi, dkk (2016) dengan hasil penelitian menunjukkan bahwa promosi jabatan tidak memiliki pengaruh positif, dan signifikan tehadap kinerja pegawai Dinas Kebudayaan Pariwisata Pemuda dan Olahraga Kabupaten Rembang. Peneliti berpendapat bahwa seringkali sebuah organisasi/ pihak manajemen memiliki rencana yang kurang tepat dalam menangani promosi, yang dimana hal ini akan memberikan hasil akhir yang negative bagi personil (perawat). Maka untuk menghindari hal tersebut dapat di lakukan penentuan dalampelaksanaan promosi, hal yang dapat dilakukan dengan memperhatikan sistem dalam perekrutmenan,, penetapan promosi dan kriteria 
pemilihan, dan melakukan identifikasi kelompok kandidat. Dengan memperhatikan hal tersbut maka pelaksanaan dalam promosi karyawan dapat memberikan hasil yang lebih baik.

\section{Pelaksanann Peningkatan pendidikan Terhadap Kualitas Pelayanan Keperawatandi di RSI Sultan Agung Semarang.}

Hasil uji hubungan pelaksanaan pendidikan terhadap kualitas pelayanan keperawatan yang dilakukan menggunakan uji bevariate yaitu uji Chi-Square dimana nilai coefficient adalah 0,147 ( $\mathrm{p}$ value $>0,05$ ). Artinya bahwa pendidikan tidak berpengaruh terhadap kualitas pelayanan keperawatan Hal ini berbanding terbalik dengan hipotesis awal yang menyatakan bahwa pelaksanaan peningkatan pendidikan dapat memberikan dampat terhadap kualitas pelayanan keperawataan, di karenakan ada asumsi yang menyatakan dengan menigkatnya jenjang pendidikan maka pengetahuan dari setiap orang akan bertambah dan akan memberikan dampak yang baik terhadap pelayanan keperawatan.

Terdapat penelitian serupa yang sejalan Riastuti (2009) mengenai hubungan pendidikan dan pelatihan dengan peningkatan kinerja perawat di Ruang Rawat Inap RSI Siti Aisyah MadiunTahun 2008 menyatakan bahwa tidak ada hubungan yang bermakna antara Pendidikan dengan peningkatan kinerja perawat diruang rawat inap RSI Siti Aisyah Madiun. Hal ini dikarenakan semua perawat dengan tingkat Pendidikan dapat memberikan pelayanan yang baik.

\section{Pelaksanann Pelatihan Terhadap Kuaitas Pelayanan Keperawatan di di RSI Sultan Agung Semarang.}

Hasil uji hubungan pelaksanaan pelatihan terhadap kualitas pelayanan keperawatan yang dilakukan menggunakan uji bevariate yaitu uji Chi-Square dimana nilai coefficient adalah 0,746 ( $\mathrm{p}$ value $>0,05$ ). Artinya bahwa pelatihan tidak berpengaruh terhadap kualitas pelayanan keperawatan Hal ini berbanding terbalik dengan hipotesis awal yang menyatakan bahwa pelaksanaan peningkatan pelatihan dapat memberikan dampat terhadap kualitas pelayanan keperawataan , di karenakan ada asumsi yang menyatakan dengan menigkatnya jenjang pendidikan maka pengetaahuan dari setiap orang akan bertambah dan akan memberikan dampak yang baik terhadap pelayanan keperawatan.

Hal ini sesuai dengan hasil penelitian terdahulu yang dilakukan oleh Indah Mawarti (2014) di RSUD Jambi, Yang dimana tidak terbukti adanya hubungan antara pelatihan dengan pelaksanaan sistem pemberian pelayanan keperawatan profesional oleh perawat pelaksana, dimana perawat yang tidak mengikuti pelatihan lebih baik dalam pelaksanaan kerja.

\section{SIMPULAN DAN SARAN}

Berdasarkan hasil penelitian yang telah dilakukan dan dilihat dari hasil analisis beserta pembahasan, maka diperoleh kesimpulan penelitian tentang "Pengembangan Karir Perawat Berbasis Kebijakan Rumah Sakit Terhadap Kualitas Pelayanan Keperawtan di RSUD Tugurejo Semarang dan RSI Sultan Agung Semarang", (1) Ada hubungan yang bermakna antara pelaksanaan rotasi 
mutasi dengan kualitas pelayanan keperawatan di RSUD Tugurejo Semarang. (2) Tidak ada

hubungan yang bermakna antara pelaksanaan promosi dengan kualitas pelayanan keperawatan di RSUD Tugurejo Semarang. (3) Tidak ada hubungan yang bermakna antara pelaksanaan meningkatan tingakat pendidikan dengan kualitas pelayanan keperawatan di RSUD Tugurejo Semarang. (4) Tidak ada hubungan yang bermakna antara pelaksanaan pelatihan dengan kualitas pelayanan keperawatan di RSUD Tugurejo Semarang. (5) Tidak ada hubungan yang bermakna antara pelaksanaan rotasi mutasi dengan kualitas pelayanan keperawatan di RSI Sultan Agung Semarang. (6) Tidak ada hubungan yang bermakna antara pelaksanaan promosi mutasi dengan kualitas pelayanan keperawatan di RSI Sultan Agung Semarang. (7) Tidak ada hubungan yang bermakna antara pelaksanaan peningkatan tingkat pendidikan dengan kualitas pelayanan keperawatan di RSI Sultan Agung Semarang. (8) Tidak ada hubungan yang bermakna antara pelaksanaan pelatihan dengan kualitas pelayanan keperawatan di RSI Sultan Agung Semarang.

Hasil penelitian ini sekiranya dapat dijadikan sebagai salah satu bahan referensi dan kajian pada bidang ilmu keperawatan, khususnya dibidang manajemen keperawatan terkait dengan pengembangan karier perawat dengan kualitas pelayanan keperawatan. Walaupun pengembangan karir yang dirasakan sudah cukup baik bagi perawat pelaksana, namun perlu adanya peningkatan pada bagian pelaksanaan promosi, pendidikan, dan pelatihan kepada perawat pelaksana. Sehingga kedepan pengambangan karir perawat semakin baik dan perawat dapat menentukan bakat, peningkatan kompetensinya hingga perawat dalam memberikan pelayanan keperawatan semakin professional sesuai dengan kualifikasi yang dimiliki dan berdampak terhadap kualitas pelayanan keperawatan. Sebagai upaya dalam peningkatan kualitas pelayanan keperawatan, penting dimiliki oleh perawat ruangan adalah kemampuan mengaplikasikan pelayanan keperawatan dengan profesionalitas yang tinggi. Salah satu hal yang dapat dilakukan adalah meningkatkan kompetensi yang dimiliki melalui pelatihan, peningkatan pendidikan. Upaya tersebut merupakan salah satu bentuk di dalam meningkatkan kompetensi yang dimiliki dalam memberikan kualitas pelayanan keperawatan.

\section{UCAPAN TERIMA KASIH}

Apabila dibutuhkan, tuliskan ucapan terima kasih kepada pihak-pihak yang terlibat dalam proses penelitian. Apabila dibutuhkan, tuliskan ucapan terima kasih kepada pihak-pihak yang terlibat dalam proses penelitian

\section{DAFTAR PUSTAKA}

Dessler, Gary. (2007), Manajemen Sumber Daya Manusia Edisi Kesepuluh Jilid 2, Terjemahan, Paramitha Rahayu, Jakarta: PT Indeks

Departemen Kesehatan, Pedoman Pengembangan Jenjang Karir Profesional Perawat. Direktorat Bina Pelayanan Keperawatan Direktorat Jenderal Bina Pelayanan Medik Departemen Kesehatan RI. Jakarta. 2006. 
Handoko, T. Hani. (2001), Manajemen personalia dan Sumber Daya Manusia, Yogyakarta: BPEE.

Kementrian kesehatan Indonesia (2015). Jakarta : kementrian kesehatan RI 2016

Marquis, B. L. \& Huston, C. J. (2010). Kepemimpinan dan manajemen keperawatan : teori dan aplikasi, (Ed. 4). Jakarta : EGC

Mawarti (2014) Analysis Faktor-faktor Yang Berhubungan Dengan Pelaksanaan SYSTEM Pemberian Pelayanan Keperawatan Profesional Olwh Perawat

Notoatmodjo, S. (2010). Ilmu Perilaku Kesehatan. Jakarta: Rineka Cipta

Nursalam.(2011). Proses dan dokumentasi keperawatan, konsep dan praktek.Jakarta :Salemba Medika.

Nursalam. (2014). Manajemen keperawatan aplikasi dalam praktik keperawatan profesional edisi 4. Jak Sugiyono. (2011). Metode penelitian kuantitatif kualitatif dan R \& D. Bandung : Alfabetaarta : Salemba Medika.

Nursalam. (2008). Konsep Dan Penerapan Metodologi Penelitian Ilmu keperawatan. Edisi 2. Jakarta : Salemba Medika

Nursalam. (2011). Manajemen Keperawatan.edisi 3. Jakarta : Salemba Medika.

Tjiptono, Fandi\& Chandra,Gregorius. (2005). ServiceQualitydan satisfaction. Yogyakarta : Andi

Prayetni, SKp.MKep. Jenjang Karir Perawat. Direktorat Bina Pelayanan Keperawatan Kementrian Kesehatan RI. 2011.

Robbins SP, dan Judge. (2007). Perilaku Organisasi. Alih Bahasa Drs. Benyamin Molan Jakarta : Salemba Medik

Teguh Sulistiyani dan Rosidah, Manajemen Sumber Daya Manusia, (Yogyakarta : Graha Ilmu). 2009.

Siagian, Sondang P. (2008), Manajemen Sumber Daya Manusia, Jakarta: PT Bumi Aksara. 